\title{
Partnership preferences of the Belgian second generation: Who lives with whom?
}

\author{
Anne Hartung ${ }^{\mathrm{a}, *}$, Véronique Vandezande ${ }^{\mathrm{b}}$, Karen Phalet ${ }^{\mathrm{c}}$, Marc Swyngedouw $^{\mathrm{c}}$ \\ ${ }^{a}$ University of Leuven \& CEPS/INSTEAD, Belgium \\ ${ }^{\mathrm{b}}$ Department of Well-Being, Public Health and Family, Flemish Government, Belgium \\ c University of Leuven, Belgium
}

\section{A R T I C L E I N F O}

\section{Article history:}

Received 17 November 2010

Received in revised form 7 September 2011

Accepted 7 September 2011

\section{Keywords:}

Second generation

Belgium

Intermarriage

Inter-ethnic partnerships

\begin{abstract}
A B S T R A C T
Divergent bodies of theory have devoted ample attention to ethnic intermarriage. Using the data from the Belgian TIES project (The Integration of the European Second Generation), this paper focuses on the young Turkish and Moroccan second generation in Belgium and, in contrast to other studies in the field, includes cohabitation in addition to marriages. Furthermore, it distinguishes not only partnerships to natives versus partnerships to nonnatives but three types of partnerships: those to first generation partners, second generation partners and 'native' Belgian partners.

Our results show, first, that a large part of the second generation lives with first generation coethnic partners. We find secondly that most of the relations to Belgian-born persons are in fact relations to partners of second generation from the same ethnic background. We conclude that estimations of intermarriage/cohabiting unions based on relations to first generation immigrants seriously underestimate the extent of intra-ethnic partnerships. Thirdly, we find that not only individual characteristics but also the social environment impacts on the partner choice.
\end{abstract}

Crown Copyright $\odot 2011$ Published by Elsevier Ltd. All rights reserved.

\section{Introduction}

Divergent bodies of theory have devoted ample attention to ethnic intermarriage, exogamy and ethnic assortative mating. Marriage is often regarded as an indicator of the transmission of ethnically specific cultural values and practices. Song (2009: 332f) explains why intermarriage is considered so important for theorists: for them intermarriage is a practice which may fundamentally affect the boundaries between ethnic minority groups (Barth, 1969). Specifically, increasing rates of intermarriage might signal fading or shifting boundaries and decrease ethnic prejudices (Kalmijn, 1991). This should be similar for inter-ethnic unions in general, on which we focus here. In a nutshell, this article looks at patterns of

\footnotetext{
* Corresponding author. Tel.: +352 585855452.

E-mail address: anne.hartung@ceps.lu (A. Hartung).
}

inter- and intra-ethnic cohabiting partnerships ${ }^{1}$ of the descendants of Turkish and Moroccan immigrants (i.e. the second generation) in Belgium based on the Belgian data from the TIES project (The Integration of the European Second Generation). Despite Belgium's large ethnic population and the extensive literature in traditional immigration countries, there are only a few studies on intermarriage and interethnic unions in Belgium to date.

From the 'golden sixties' onward, Belgian migration statistics show a large and steady intake of foreign labour in the heavy metal and mining industries from rural areas of Southern countries, such as Turkey and Morocco. Increasingly, foreign workers were also contracted by employers in other industries, construction, and menial

\footnotetext{
${ }^{1}$ We look at inter-ethnic partnerships comprising married and nonmarried cohabiting unions. We refer, however, to the stricter sense of 'intermarriage' to quote studies.
} 
jobs. From the middle of the 1970s, Belgium adopted a restrictive migration policy and the since then main influx resulted from family reunification and later family formation (Reniers, 1998). This has profoundly changed the nature of foreign populations: from temporary guest workers to residing households and minority communities. Due to the timing of this migration and the relatively high fertility of the first generation immigrant population, the current Turkish and Moroccan communities in Belgium have an atypically young age structure (Lesthaeghe, 2000).

It is difficult to find numbers on foreign origin populations in Belgium, since most statistics are based on nationality rather than ethnic background. When considering more inclusive categorisation criteria the Turkish origin population is estimated around $2.4 \%$ of the total population in Antwerp and 3.7\% in Brussels. For the Moroccan origin population this is $7.5 \%$ in and $12.9 \%$ in Brussels (Vandezande, Phalet, \& Swyngedouw, 2011).

Findings based on the Belgian Census of 1991 suggest that there is a high share of marriages with a co-ethnic from the country of origin among those with a Turkish and Moroccan nationality who migrated to Belgium prior to marriage in the period between 1960 and 1990. The share of such cross-border marriage to a co-ethnic is higher for Turkish nationals (75\% for men and $69 \%$ for women) than for Moroccan nationals living in Belgium (57\%) (Lievens, 2000). Also, the second generation of Turks and Moroccans show relatively high and stable rates of marriage with a coethnic partner from the country of origin (Corijn \& Lodewijckx, 2009; Lievens, 1997; Lodewijckx, 2010; Reniers \& Lievens, 1997; Reniers, 1998). Similar results were found for the Netherlands: Moroccans and Turkish migrants were found to be (among) the groups least open to interethnic marriage and cohabitation (Kalmijn \& van Tubergen, 2007). Therefore, this study explores further the partnership patterns of the two largest second generation groups in Belgium, the Moroccan and Turkish second generation. As the second generation in Belgium have come of age in the last years, it is a good time to study family formation in these populations. In addition, the process of union and family formation among ethnic minorities undergoes a rapid change in Belgium: they assimilate in terms of marriage age and number of children (Schoenmaeckers, Lodewijckx, \& Gadeyne, 1999).

Many empirical studies have the shortcoming of merely focusing on "who marries whom?", i.e. are limited to the concept of intermarriage and exclude partnerships or cohabitations (Song, 2009). In other words, this approach ignores important recent societal changes. Over the last decades, cohabitation has become a relevant form of living together (Corijn \& Klijzing, 2001; Corijn, 2010). Today many Western countries provide alternative legal alternatives to marriage such as officially recognised partnerships (e.g. Pacte civil de solidarité (PACS) in France, samenlevingscontract/contrat de vie commune in Belgium). Literature on assortative mating on educational matching between the partners takes increasingly into account that young cohorts tend to live together first rather than directly getting married. Corijn (2010) shows that people living together before a possible marriage are generally higher educated and more often non-religious. Yet, due to data limitations, to date there are only few studies on inter-ethnic partnering who include also cohabiting unions (Blackwell \& Lichter, 2000; Corijn \& Lodewijckx, 2009; Kalmijn \& van Tubergen, 2007).

In addition, the operational definition of inter-ethnic union often collapses different "types" of partnerships. When differentiating by nationality, partnerships to the second generation are - depending on the country's degree of openness towards naturalisations - often collapsed with either first generation partnerships (when restricted access to nationality) or are assigned to the 'native' category (when open access to nationality). This second drawback related to the question "who marries whom?" Throwing light on these additional dimensions, our paper remedies this situation and thus contributes to the empirical literature in the field in two ways. First, we look at the more generally defined concept of union formation or partnership including marriages and also cohabitation. Secondly, we distinguish partnerships to first generation migrants, second generation and natives. In other words, we apply a more precise concept of interethnic unions.

This relates to the first aim, which is of methodological nature, namely to compare definitions of inter-ethnic partnerships and its empirical implications: first versus second generation versus Belgian partners. In doing so, we define partnerships - or unions - as couples living together, married or unmarried. Couples that are legally bound but not living together are thus not considered. Although the number of non-married cohabiting couples among the Turkish second generation is still relatively small, the share is increasing not only for natives but also for Moroccans in Belgium, the Moroccan second generation and for those with "native" partners (Corijn \& Lodewijckx, 2009: 22ff; Schoenmaeckers et al., 1999).

This article first reviews the literature in the field of inter-ethnic partnerships and then introduces the methodology of the study. We then present descriptive results on inter- and intra-ethnic partnerships in Belgium and estimate a multinomial logistic regression to model the factors facilitating interethnic partnerships and conclude in the final section. In other words, the second aim is to predict partner choices of the second generation and scrutinise the assimilation argument.

\section{Literature review}

As mentioned, many studies do not distinguish between first generation partners, second generation partners and native partners. Collapsing second generation partners as first generation or natives may cause problems for cross-country comparisons and for substantive reasons. $^{2}$ Conceptually, such approaches must over- or underestimate the true rate of inter-ethnic unions. In

\footnotetext{
${ }^{2}$ Apart from methodological reasons, the differentiation between these different kinds of partnerships also seems to be important for substantive reasons. It poses the theoretical question if partnerships between members of the first and second generation are to be considered as inter- or intra-ethnic marriages. This question, however, shall not be discussed here.
} 
countries whose access to citizenship can be characterised as open - like Belgium - the second generation will tend to be naturalised. If the partner is a native Belgian, this would be categorised as intra-ethnic marriage if based on nationality, but as inter-ethnic marriage if based on country of origin. In countries with a more restrictive citizenship law, this case will turn out completely different. It is therefore important in our eyes to look at both definitions separately. We expect that the conceptualisation matters and that looking at partnerships with persons born in Belgium (including thus the second generation) overestimate the probability of interethnic partnerships severely (H1). As rates of cohabitation are higher than marriage rates (Corijn \& Lodewijckx, 2009), inter-ethnic marriage is an unsatisfactory indicator of inter-ethnic partnership.

A similar point is also raised by Reniers and Lievens (1997) who claim that, at least in the Belgian case, it is not very useful or sufficient to talk about 'interethnic' marriages. More specifically, they found that the vast majority of the second generation engaged in a marriage with a partner from their parents' home country, Turkey or Morocco, who comes to Belgium to marry them. The researchers found that people married with a co-ethnic from the country of origin and people who married to a coethnic raised in Belgium differ significantly. These studies argue that it is important to distinguish between the migration generations of the partners and they show that the social and symbolical functions of both types of marriages can be quite different (Lodewijckx, 2010; Reniers, 1998). This reveals the problem of defining what exactly an interethnic partnership is. Song (2009: 338) rightly points out that "if the boundaries between groups are in flux and are fundamentally messy, how are we to know which marriages count as incidents of intermarriage?". She argues that a differentiation by nativity is questionable, since differences between new immigrants, second and third generations are perceived as substantial. Taking these arguments into account, a generational approach seems most appropriate.

After discussing different conceptualisations of interethnic partnerships, a next question to ask is what the underlying dynamics of a differential partner choice are. Three different strands of explanations can be distinguished in the literature on inter-ethnic partnerships: preferences, opportunities and third parties (Kalmijn, 1998; Kalmijn \& van Tubergen, 2007). These strands look on marriage behaviour either from a micro or a macro perspective. On the micro level, it is claimed that individuals prefer to marry someone with similar background characteristics such as ethnicity (ethnic matching hypothesis). ${ }^{3}$ Gordon (1964) argues that the most assimilated migrants are more prone to have partners from the majority.

\footnotetext{
${ }^{3}$ Yet, the competing economic competition hypothesis claims that individuals prefer to marry someone of higher economic status (Kalmijn, 1994, assortative mating by cultural and economic occupational status). Kalmijn (1994) for instance found that cultural assortative mating is more important than assortative mating by occupational status.
}

Blau, Blum, and Schwartz (1982) views intermarriage from a macro perspective and explains the probability of intergroup contacts - and thus also intermarriage - by structural or contextual determinants, which create or limit (contact) opportunity and choices. Such structural factors are for instance the size of the ethnic group, heterogeneity (of one's surrounding) (Blau et al., 1982) but also degree of urbanisation of the place of origin (Huschek, Liefbroer, \& de Valk, 2010; Lievens, 1998).

Studies on interethnic partnerships in Belgium are rare (Lievens, 1998). Lievens (1998) for instance investigates marriage behaviour of the two biggest migrant groups living in Belgium, Turks and Moroccans and finds that both individual and higher-level factors determine the partner choice. However, based on census data, Lievens' study (1998) is limited to married couples and takes merely nationality and country of birth as the indicator for the ethnic groups. This excludes by definition the naturalised second generation, which is born in Belgium. This is a particular problem when using recent data as the access to Belgian nationality was liberalised in 2000. Since then a large group of the second generation in Belgium is naturalised and only possible to identify via information on the parents.

Yet, the results are of utter importance. Most of the studies include age at marriage, which is seen as an indicator of maturity and independence, as a predictor and find that the likelihood to intermarry increases with age (Kalmijn \& van Tubergen, 2007; Lievens, 1998). This is also hypothesised here (H2). Huschek et al. (2010) reveal that the timing of the first union among the Turkish second generation in Europe is not only influenced by personal characteristics but also those of peers and parents. Interethnic contacts as well as low human capital and rural origin of the parents have a postponing effect on entry to the first union. ${ }^{4}$ Unfortunately, their empirical analysis only includes the Turkish second generation and does not investigate the effect of those on the propensity to have a partner with a different ethnic background. Yet other studies find that endogamous, patrilineal family systems hinder intermarriage (Lucassen \& Laarman, 2009). Anthropological research on the Netherlands suggests that traditional patterns are imported from the cultures of origins and maintained in the receiving society (Van der Hoek \& Kret, 1992). These studies find that regarding the partner choice, to which a large importance is attached among unmarried young persons and their families, strong social control, especially on girls, is exerted. Lodewijcks et al. (1997 cited in Lievens, 1998) find a trend towards an increasing degree of liberty and participation in this decision, which is more pronounced in the Moroccan group and yet that the parents largely preserve a considerable degree of influence. We expect thus that the opinion of the parents impacts on the partner choice: the probability of being in an interethnic partnership diminishes/increases with the parents' rejection/approval (H3).

\footnotetext{
${ }^{4}$ In fact, the authors show in a second step that this is an indirect effect via the educational attainment of the child.
} 
Due to intergenerational bonds and transmission of confessions, results on the family background must also be seen in light of religious orientation. Results on the US suggest that while differences in religion diminish the propensity to intermarry, intermarriages have become more common in liberal religious groups (Sherkat, 2004). Endogamy rates were found to be particularly high in Hindu and Muslim communities (Lucassen \& Laarman, 2009; compare also van Tubergen \& Maas, 2007 on the Netherlands). However, we believe that it is not being ascribed to a religious category but to what extent religion matters in one's personal life that affects the partner choice. Religion may be considered as an important part of one's identity and thus cultural continuity. Thus, interethnic partnerships are less likely when partners attach differently to religion and religious involvement ( $\mathrm{H} 4)$.

We also expect stark differences across the cities in Belgium. Migration patterns led to a different profile of the first generation groups across these cities. Lesthaeghe (2000) notices a so-called "persistent Antwerp-effect" in his study on modernity in Turkish and Moroccan women: he finds that religious and traditional conformity are stressed significantly more in Antwerp than elsewhere. He explains this as a reaction to a high extreme-right vote among Belgians in this city. Asserting their religious and ethnic authenticity is seen as a reaction against Belgian ethnocentrism. Similarly Vandezande et al. (2011) find that higher shares of the second generation Turks and Moroccans report discrimination in the public domain in Antwerp than in Brussels. This perceived hostility might also decrease the probability of interethnic partnering in Antwerp (H5). Besides, union formation among the Turkish second generation occurs earlier in Antwerp than in Brussels (Corijn \& Lodewijckx, 2009). If this also affects the likelihood of having an inter-ethnic partner has not been investigated to date.

In line with other studies (Corijn \& Lodewijckx, 2009; Kalmijn \& van Tubergen, 2007; Lievens, 1998; Schoenmaeckers et al., 1999; Sherkat, 2004), it is expected that the propensity to intermarry increases not only with age but also with higher educational attainments (H6). Higher education can create additional opportunities for minority members to establish contacts with peers from a different ethnic background.

Much research investigated gender differences in (inter)marriage behaviour (Qian \& Lichter, 2001). In general, men are found more likely to be in an interethnic union (Kalmijn \& van Tubergen, 2007). Corijn and Lodewijckx (2009) find that in particular Moroccan men have more often partners with a different ethnic background. It is reasoned that women take care of the children and thus are exposed to more pressure by third parties. An important role may also be the fact that for many religions, women are the transmitter of faith. Briefly, we expect that men are more likely to have a partner from a different ethnic background (H7).

Regarding the wider definition of partnership, it is hypothesised (H8) that both married as well as cohabiting couples are very homogamous regarding ethnicity but that mate selection processes differ for cohabiting and married couples: cohabiting couples tend to be less homogamous than married couples (Blackwell \& Lichter, 2000). Kalmijn and van Tubergen (2007: 378) summarise that the "norms of endogamy will be applied less strictly to cohabiting unions than to marriages." Cohabiting relationships are often seen as looser bonds, in which certain ascribed characteristics of the partner are less important. From a different perspective, cohabiting relationships can be seen as trial marriages. If the more heterogeneous couples tend to split up more often, marriages as "successful relationships" should differ systematically from cohabiting unions, so for instance Blackwell and Lichter (2000).

\section{Methodology}

\subsection{Data}

The present analysis is based on the Belgian TIES data (The Integration of the European Second generation), which is part of the cross-national TIES survey on the trajectories and experiences of the second generation in several European cities (Swyngedouw, Phalet, Baysu, Vandezande, \& Fleischmann, 2008). The advantage of using the TIES dataset is the large variety of variables on the ethnic background. For Belgium, the TIES data was collected interviewing the Turkish and Moroccan second generation - and a Belgian control group - aged 18-35 in Antwerp and Brussels. The second generation in this survey is defined as local-born persons with at least one parent born in Turkey or Morocco; the native control group is defined as having two Belgian born parents. The total sample consists of 1717 persons. As the native population was sampled in the same urban districts, the design allows to controls for neighbourhood and some background characteristics. The sample is corrected by a weight based on information on age, gender and municipality from the population register of the city of Antwerp (Antwerp subsample) and the 2001 census (Brussels subsample). Swyngedouw et al. (2008) conclude that "the Turkish sample represents the Belgianborn population of Turkish descent in Antwerp well in terms of its age by gender by district distribution, whereas the native Belgian and Moroccan samples deviate from the population distributions in some respects" (Swyngedouw et al., 2008: 23) and "that the unweighted TIES samples do not represent the age by gender by municipality distributions of the second generation populations in Brussels." (Swyngedouw et al., 2008: 24) The data used here is weighted and adjusted for these deviations and represents thus the population in the two cities. It is, however, important to note that the survey is not representative for all Belgian natives, but for the Belgian population living in same neighbourhoods as the Turkish and Moroccan minorities.

\subsection{Sample}

The first part of the descriptive results is based on the complete data $(N=1717)$ including the Belgian second generation and the "native" population - whether cohabiting with a partner or not. For the second part of the descriptive results and the multivariate analysis, we included only the Belgian second generation who were 
Table 1

Descriptive sample statistics of the dependent and independent variables.

\begin{tabular}{|c|c|c|c|}
\hline & Mean & $\begin{array}{l}\text { Standard } \\
\text { deviation }\end{array}$ & Description \\
\hline \multicolumn{4}{|l|}{ Type of partner: } \\
\hline (ref.: ‘Native’ Belgian partner) & & & Partner born in Belgium and both parents born in Belgium \\
\hline First generation partner & .692 & .462 & Partner born in Turkey or Morocco respectively \\
\hline Second generation partner & .183 & .387 & $\begin{array}{l}\text { Partner born in Belgium but at least one parent } \\
\text { born in Turkey or Morocco }\end{array}$ \\
\hline City: Brussels (ref.: Antwerp) & .348 & .477 & Dummy \\
\hline $\begin{array}{l}\text { Ethnic group: Moroccan 2nd } \\
\text { generation (ref.: Turkish 2nd gen.) }\end{array}$ & .424 & .495 & $\begin{array}{l}\text { Ethnic group membership defined by the parent's } \\
\text { country of birth }\end{array}$ \\
\hline Age of respondent & 28.8 & 4.004 & In years \\
\hline Gender: Women (ref.: men) & .560 & .497 & Dummy \\
\hline Cohabitation only (ref.: married) & .076 & .263 & $\begin{array}{l}\text { Partners are not married but live together in the } \\
\text { same household }\end{array}$ \\
\hline \multicolumn{4}{|l|}{ Respondent's education: } \\
\hline Medium & .552 & .498 & Higher secondary \\
\hline Higher & .256 & .437 & Tertiary and higher education \\
\hline \multicolumn{4}{|l|}{ Mother's education: } \\
\hline Medium & .151 & .359 & Higher secondary \\
\hline Higher & .020 & .359 & Tertiary and higher education \\
\hline Missing & .409 & .492 & Response missing \\
\hline Number of native friends & 3.051 & 1.029 & Categorical, ranging from 1 "none" to 5 "most of them" \\
\hline Parental pressure for divorce (ref.: no) & .120 & .324 & Dummy \\
\hline Relatives in the city (ref.: yes) & .182 & .386 & Dummy \\
\hline Being Belgian not socially relevant (ref.: yes) & .314 & .465 & Dummy \\
\hline $\begin{array}{l}\text { Being Turkish/Moroccan not socially } \\
\text { relevant (ref.: yes) }\end{array}$ & .100 & .301 & Dummy \\
\hline Being Muslim not socially relevant (ref.: yes) & .096 & .295 & Dummy \\
\hline Heritage culture maintained at home & 1.797 & 1.033 & 5 item scale from "totally agree" to "totally disagree" \\
\hline
\end{tabular}

Source: TIES (Belgium), Turkish and Moroccan second generation with partners only, data not weighted.

living together with a partner $(N=509)$. While the aim of the construction of the first sample is to compare singles to non-singles, and Belgians to the Moroccan and Turkish second generation, the objective of the multivariate analysis is to contrast partner choices of the ethnic minorities. In other words, the sample accordingly only contains cases from the second generation in Belgium, not from "native" Belgians. Cases with partners from another ethnic background (neither Belgian, nor Moroccan or Turkish) were also disregarded.

\subsection{Estimation technique}

Multinomial logistic regressions (polytomous logistic regression) are used when the dependent variable is measured at the nominal level and is not dichotomous, as for instance the present case of different forms of partnerships (see Table 1).

Multinomial logistic regressions estimate with which probability an expected event will occur depending on different impacting variables (Backhaus, Erichson, Plinke, \& Weiber, 2006: 426). In this sense, it is an appropriate method for predicting the partner choice and the impacting factors. Put differently, our aim is to give a profile of the persons in inter- and intra-ethnic partnerships and investigate how different or similar these "groups" are. In technical words, the logistic regression allows to identify the weights with which the predictors influence the probability that an observed individual belongs to one of the distinguished groups. In doing so, odds are reported. Rather than describing the probability of an event, odds indicate the relation of a probability to the counter probability: event $y=1$ is compared to event $y=0$ (Backhaus et al., 2006):

Odds $(y=1)=\frac{p(y=1)}{1-p(y=1)}$

\subsection{Operationalisation and variables}

The literature review made clear that it is very useful to look at the individual profiles but also the context as it can give an insight in marriage strategies and opportunities/ constraints. The included individual- and contextual-level variables are defined as follows (for descriptive sample statistics see Table 1 ).

Ethnicity distinguishes Belgian natives from the Turkish and Moroccan second generations. Belgian natives are defined as persons with both parents born in Belgium. The second generation comprises persons with at least one parent of Turkish or Moroccan origin.

Our paper builds on and extends the insights on intermarriage in two ways. First, we do not only look at 
marriages but include also cohabitation. In other words, partnership is measured at the time of the interview and includes cohabitating couples, either married or unmarried. First generation partners, second generation partners, 'native' Belgian partners and partners with another background are distinguished via nationality and the country of origin of the parents. The ethnicity of the partner is thus defined in the same way as the respondent's ethnic group.

The parents involvement in their children's partner choice are measured with two dichotomous questions (no/ yes) - one on parental pressure to marry and one on parental pressure to separate from the partner.

Two indicators characterise the social surrounding of the person. The first one identifies if family is present in the city of residence. The second one refers to one's network in the past (in order to avoid endogeneity issues) and indicates how many friends are of Belgian origin ranging from none via 'one or a few', 'quite a few', 'a large number of them' to 'most of them'.

The subjective social relevance of (1) being Belgian, (2) being Turkish/Moroccan and ( 3 ) being Muslim is measured dichotomously (yes/no). The question if the cultural heritage is maintained at home was measured on a 5item scale from 'totally agree' to 'totally disagree' and had thus a neutral mid-point ('neither agree nor disagree'). Note that, as these concepts were measured at the time of being in a specific type of partnership, causality cannot clearly be established between these independent variables and the dependent variable.

Education is measured as the highest diploma attained or, for the respondents still in school, the current educational level. These ISCED levels are regrouped into three categories: (1) no diploma, primary or lower secondary, (2) higher secondary and (3) tertiary or higher education.

\section{Inter- and intra-ethnic partnerships in Belgium}

This section presents, first, selected descriptive results and, second, a multivariate analysis predicting the type of partnership for the Belgian second generation. Before describing the different forms of partnerships, the first part will give a profile of the persons who actually are in union compared to those who are not. The focus of this first part is therefore to compare the Turkish and Moroccan second generation in Belgium to "native" Belgians - how do persons in union differ from single persons? Are there differences across the ethnic groups? The second part of the descriptive section will focus on the different types of partnerships. The aim is here to put order in the conceptual 'messiness' of interethnic partnerships by distinguishing relations to a first-generation migrant from secondgeneration and "native Belgian" partners. Then, the partner choice is modelled. In this part, only the Moroccan and Turkish second generations are included.

\subsection{Describing the different types of partnerships}

Looking at the full sample, there is a significantly higher share of persons living without partner among Belgian
Table 2

Types of partnerships, by ethnic group (column percentages).

\begin{tabular}{lcccc}
\hline & Native & Turkish & Moroccan & \multirow{2}{*}{$N$} \\
\hline Living without partner & 67.3 & 49.8 & 59.7 & 1008 \\
Living with partner, of which: & & & & \\
Belgian partner $^{\mathrm{a}}$ & 81.4 & 11.1 & 12.6 & 211 \\
Second generation partner $^{\mathrm{a}}$ & 10.8 & 16.3 & 19.9 & 113 \\
First generation partner & 7.8 & 70.7 & 61.1 & 364 \\
Partner other origin & 0.0 & 2.0 & 6.4 & 20 \\
Total (living with partner) & 100.0 & 100.0 & 100.0 & 1717 \\
\hline
\end{tabular}

Source: TIES (Belgium), weighted data.

a Born in Belgium.

natives than among the Moroccan second generation, whose share is again significantly greater than those of the Turkish second generation (compare Table 2, $\left.p\left(\mathrm{Chi}^{2}\right)=.000\right)$. In this sense, the Moroccan second generation is more similar to Belgians than the Turkish second generation. The share of such "singles" is moreover higher among men than among women. These results have to be seen in the light of age differences in forming the first union. The average person is 22 years when forming the first union (cohabitation incl. marriage). Compared to Belgian natives, the second generations of Turks and Moroccans enter such stable partnerships at a significantly younger age (as they have a lower share of persons living without partner in this age group). Natives are on average significantly but only slightly older (24 years) when moving together for the first time than Moroccans (23 years), who are again significantly older than the Turkish second generation (21 years).

Overall, women enter the first cohabiting partnership at a somewhat younger age than men (22 compared to 23 years, $p<.05$ ). Moroccan and Belgian males have a very similar behaviour in terms of age, they are on average 24 when entering the first cohabitation. Moroccan and Turkish females cohabitate/marry at the youngest age (21 years), while Belgian women are somewhat in between and come close to Turkish males (22 years).

The empirical material confirms also that the inclusion of cohabitations with not legally married partners is indispensible, especially when distinguishing different ethnic groups. While overall a fifth of all current cohabiting unions in our population are not marriages, only $6 \%$ among the Turkish second generation and $11 \%$ among the Moroccan second generation are not married when living together, compared to $60 \%$ among the Belgian natives. The share of unmarried cohabiting partnerships is moreover less common among women in each of these ethnic groups. Women of Turkish descent are in only $5 \%$ of the cases not married (7\% for the male Turkish second generation); women of the Moroccan second generation in $8 \%$ of the cases compared to $16 \%$ among their male counter parts (output omitted).

Looking now at the ethnic background of the partner, Table 2 reveals that Belgians living in the same neighbourhoods as the second generations have rarely partners with a different ethnic background. Four out of five Belgian natives in these neighbourhoods are living with a Belgian native partner (if in a union). This low rate of interethnic 
Table 3

Types of partnerships, by ethnic group (column percentages).

\begin{tabular}{|c|c|c|c|c|c|c|}
\hline & \multicolumn{3}{|l|}{ Men } & \multicolumn{3}{|l|}{ Women } \\
\hline & $\begin{array}{l}\text { Belgian } \\
\text { native }\end{array}$ & $\begin{array}{l}\text { Turkish } \\
\text { 2nd gen. }\end{array}$ & $\begin{array}{l}\text { Morocc. } \\
\text { 2nd gen. }\end{array}$ & $\begin{array}{l}\text { Belgian } \\
\text { native }\end{array}$ & $\begin{array}{l}\text { Turkish } \\
\text { 2nd gen. }\end{array}$ & $\begin{array}{l}\text { Morocc. } \\
\text { 2nd gen. }\end{array}$ \\
\hline Living without partner & 72.0 & 51.3 & 65.9 & 62.3 & 48.3 & 53.2 \\
\hline \multicolumn{7}{|l|}{ Living with partner, of which: } \\
\hline Belgian partner ${ }^{\mathrm{a}}$ & 89.1 & 14.8 & 18.3 & 75.3 & 7.6 & 8.3 \\
\hline Second gen. partner ${ }^{\mathrm{a}}$ & 8.5 & 19.2 & 22.0 & 12.6 & 13.5 & 18.3 \\
\hline First generation partner & 2.4 & 64.0 & 53.2 & 12.1 & 77.0 & 67.1 \\
\hline Partner other origin & 0.0 & 2.0 & 6.6 & 0.0 & 2.0 & 6.3 \\
\hline Total (living with partner) & 100.0 & 100.0 & 100.0 & 100.0 & 100.0 & 100.0 \\
\hline
\end{tabular}

Source: TIES (Belgium), weighted data.

a Born in Belgium.

partnerships among the native population is consistent with other studies. The share of inter-ethnic partnerships to Belgian natives is approximately equally high in this age-group among the Turkish and Moroccans second generation (11 and 12\%). More importantly, 71 and $61 \%$ of the partnerships of Turkish and Moroccan respectively are partnerships with someone from the first generation (Table 2, $\left.p\left(\mathrm{Chi}^{2}\right)=.000\right)$. Approximately two thirds of the partners born in Belgium are in fact partners of the second generation from the same ethnic background. Only 1 out of 8 partnerships of the second generation in Belgium is to a "native" Belgian. It can thus be concluded that a majority of the relationship to Belgian nationals are in fact relations to second generation Turkish or Moroccans. These results confirm the expectations stated in $\mathrm{H} 1$ that estimations of intermarriage/partnerships based on relations to first generation immigrants therefore seriously underestimate the extent of intra-ethnic partnerships. This shows that it is important to make a conceptual distinction between the different types of partnerships.

The gendered distributions (Table $3, p\left(\mathrm{Chi}^{2}\right)=.000$ ) reveal that the male descendents of Turkish and Moroccan immigants is about twice as likely as their female counterparts to be in a union with a Belgian native. Interestingly, the share of interethnic partnerships is equally high when the partner's origin is elsewhere than Belgium or the country of origin. Women of the Turkish and Moroccan second generation are somewhat less likely to have a partner from the second generation but have more frequently a migrant partner from the country of origin (first generation) than men.

Lievens (1997) explains that assimilation theory assumes that marrying a first generation partner is an element of traditionalism. In his research, this assumption is refuted. His results show that it is the Turkish women with the most 'modern' characteristics (in terms of education and age at marriage) that prefer a cross-border marriage with a co-ethnic. Lievens (1997: 5) cites the qualitative research of Esveldt et al. (1995), who found that women often prefer a cross-border marriage with coethnics because local-born Turks and Moroccans are considered as "too traditional, low educated and unemployed”. Callaerts (1997) also notes in her qualitative study with Turkish Belgians that if a Belgian born Turkish girl asks her male partner to Belgium to come and live with her, this actually means that the virilocal traditions (in which the bride moves in with her family in law) are broken and even reversed. Lievens' evidence suggests that for Moroccans this choice is rather inspired by socio-economic than by traditionalist motives. Therefore, we should not automatically consider the choice for a partner coming from the country of origin as a traditional pattern, that will diminish as the integration and modernisation proceed (Callaerts, 1997; Lievens, 1997).

Also, the argument that partnerships to an immigrant take place at a very young age cannot be confirmed as such. Union formation to the local second generation start at around the same age ( 22 years). The age at entering a union with a Belgian native is with 23 years significantly higher. The age differences with regard to the type of partnership are, however, relatively small. Age patterns do not seem to correspond to what is generally seen as "modern" or "traditionalist" marriage behaviour.

The effects of education are also in line with results of previous studies. The higher educated, the more probable to live without partner. The timing of the first union occurs later with increasing education, also when looking at the descendants of immigrants only. Similarly, partners are less often married among the highest educated in this population (68\% compared to $81 \% / 86 \%$ among the lowest/ medium educated). The question is then if the ethnic differences in partnership patterns are due to educational differences across the groups. As education is likely to have a gendered effect, Table 4 is split into two parts - the left one displaying the results for the male second generation $\left(p\left(\mathrm{Chi}^{2}\right)=.014\right)$ and the right one for their female counterparts $\left(p\left(\mathrm{Chi}^{2}\right)=.002\right)$. Noticeable is that among the higher educated men and women, the share of singles is higher. Moreover, the share of the second generation with a Belgian native partner is higher among the higher educated. In addition, among them the chance to live with someone from a different origin is elevated. This confirms $\mathrm{H} 6$ predicting that the higher educated are more likely to be in an interethnic union. The chances to live with a partner coming from the country of origin are highest among the lowest educated.

H3 states that the parents' opinion has a significant impact on the partner choice. Looking now only at the 
Table 4

Types of partnership of the descendants of immigrants, by education and gender (column percentages).

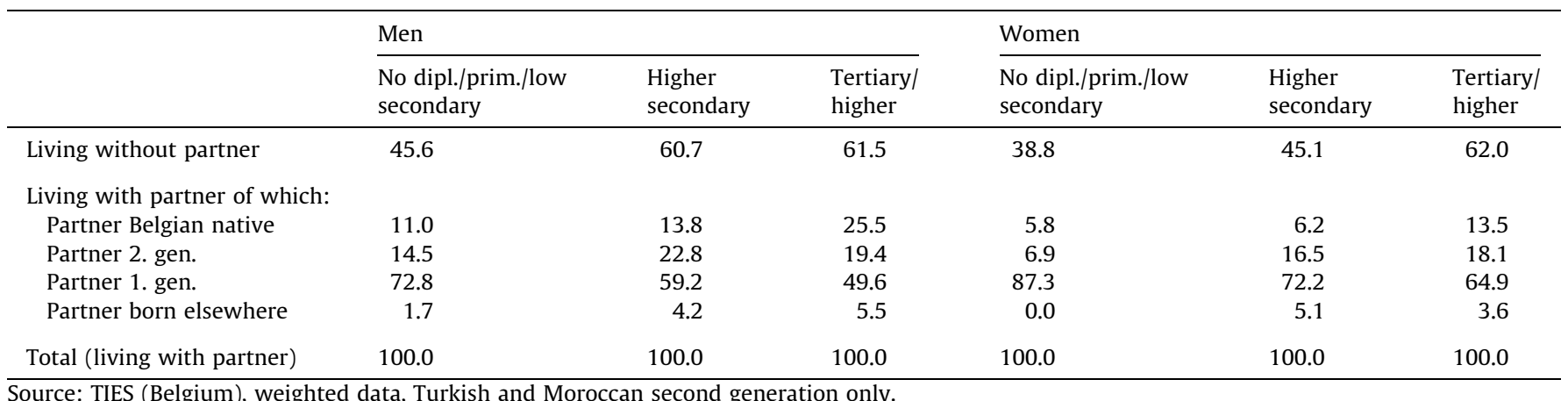

Source: TIES (Belgium), weighted data, Turkish and Moroccan second generation only.

Table 5

Pressure exerted by parents, by ethnic group and gender (column percentages).

\begin{tabular}{|c|c|c|c|c|c|c|c|}
\hline & & \multicolumn{3}{|l|}{ Men } & \multicolumn{3}{|l|}{ Women } \\
\hline & & Belgian native & Turkish 2nd gen. & Morocc. 2nd gen. & Belgian native & Turkish 2nd gen. & Morocc. 2nd gen. \\
\hline Pressure to separate & No & 92.5 & 92.3 & 85.8 & 94.6 & 84.1 & 88.6 \\
\hline \multirow[t]{2}{*}{ Pressure to marry } & No & 86.9 & 85.9 & 73.3 & 90.5 & 85.1 & 81.9 \\
\hline & Yes & 13.1 & 14.2 & 26.7 & 9.5 & 15.0 & 18.1 \\
\hline
\end{tabular}

Source: TIES (Belgium), weighted data.

Table 6

Pressure exerted by parents, by type of partnership (column percentages).

\begin{tabular}{|c|c|c|c|c|c|}
\hline & & Belgian partner & Second generation partner & First generation partner & Other partner \\
\hline \multirow[t]{2}{*}{ Pressure to separate } & No & 68.5 & 89.9 & 90.4 & 87.8 \\
\hline & Yes & 31.5 & 10.1 & 9.6 & 12.2 \\
\hline \multirow[t]{2}{*}{ Pressure to marry } & No & 78.3 & 80.6 & 84.2 & 69.5 \\
\hline & Yes & 21.7 & 19.4 & 15.8 & 30.5 \\
\hline
\end{tabular}

Source: TIES (Belgium), weighted data, Turkish and Moroccan second generation only.

sample of persons in cohabiting unions, the results suggest (Table 5) that a big majority of parents in all groups do not exert pressure; differences between groups are present, but they are relatively small. Marrying (much more than objecting their children's partner choice) in general seems to be a major concern of the parents of all ethnic groups in that age group, but not particularly for the second generation. In general, parental pressure to separate is lower for married than for cohabiting couples (14\% compared to $10 \%$; output omitted). Interestingly, in particular the Moroccan male second generation, who is more frequently living without partner, is more often exposed to parental pressure to marry and divorce than their female counterparts. Regarding the Turkish second generation, parents seem to object more often to the partner choice of women than to those of men. Putting this into perspective, also the share of native's parents that press their sons to marry/ leave their partner is very high. While Moroccans males do not differ much in this respect from the native group, Turkish men and women do.
With regard to the second generation parents' opinion regarding the origin of the partner (Table 6), there is no evidence that marriages to first-generation immigrants are more often enforced by the parents. In fact, the pressure for marrying a first generation immigrant from the same ethnic background is even lower than for marrying a second generation partner.

A striking result is moreover the subjectively reported, relatively depreciative mindset of the second generation's parents towards inter-ethnic partnerships to Belgians. Parental pressure to discourage marriages to Belgian natives is about three times higher towards Belgian partners than towards partners with the same ethnic background. On the other hand, pressure to encourage to marriage the natives partner is also highest compared to other types of partnerships. Marrying a Belgian seems to invoke a strong reaction by the parents - this seems to point into the direction that the parents would like their children to find a stable partnership. Native partners might in this regard be scrutinised carefully by the second generation's parents. 
Table 7

Multinomial logistic regression predicting partnership outcomes (odds ratios).

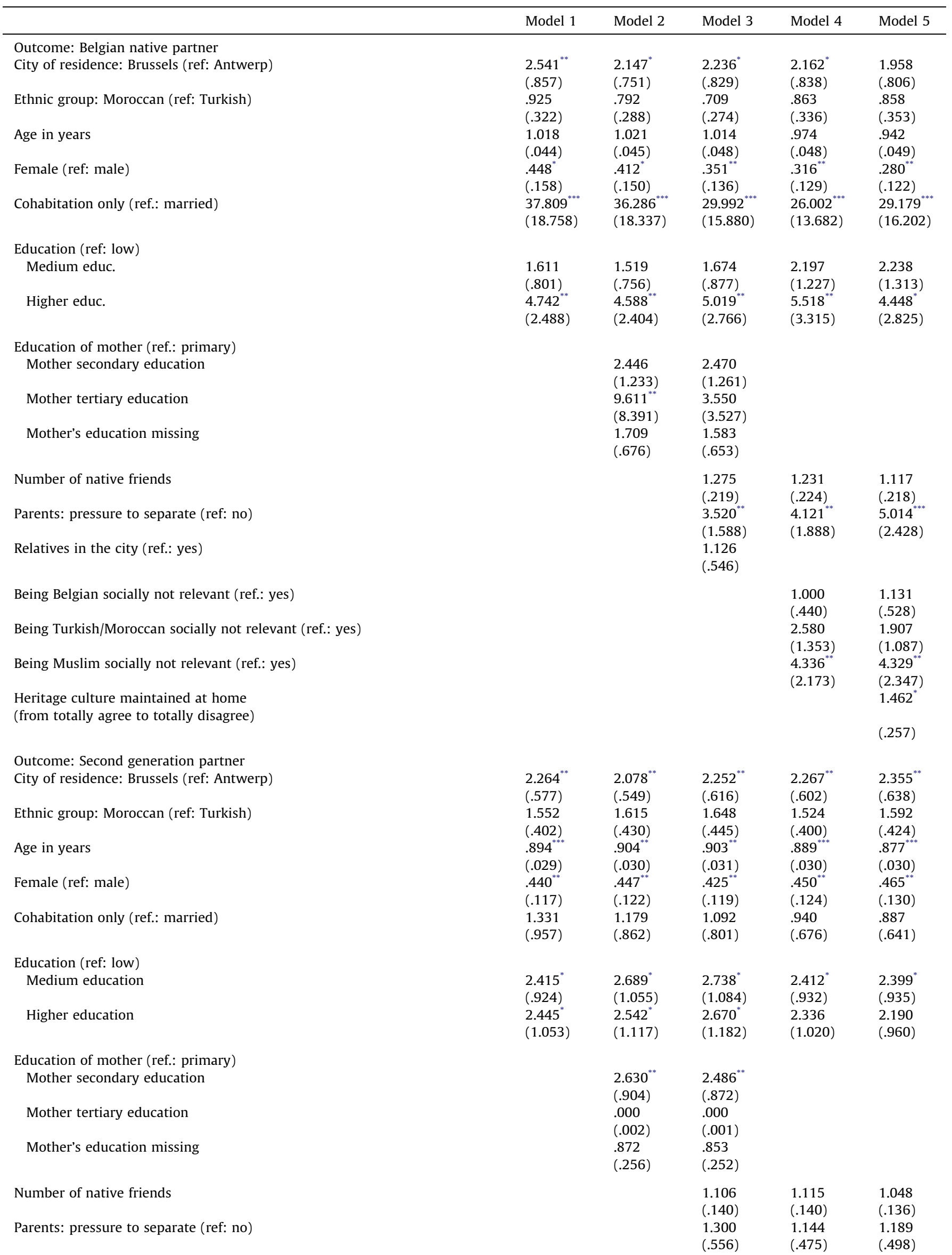


Table 7 (Continued)

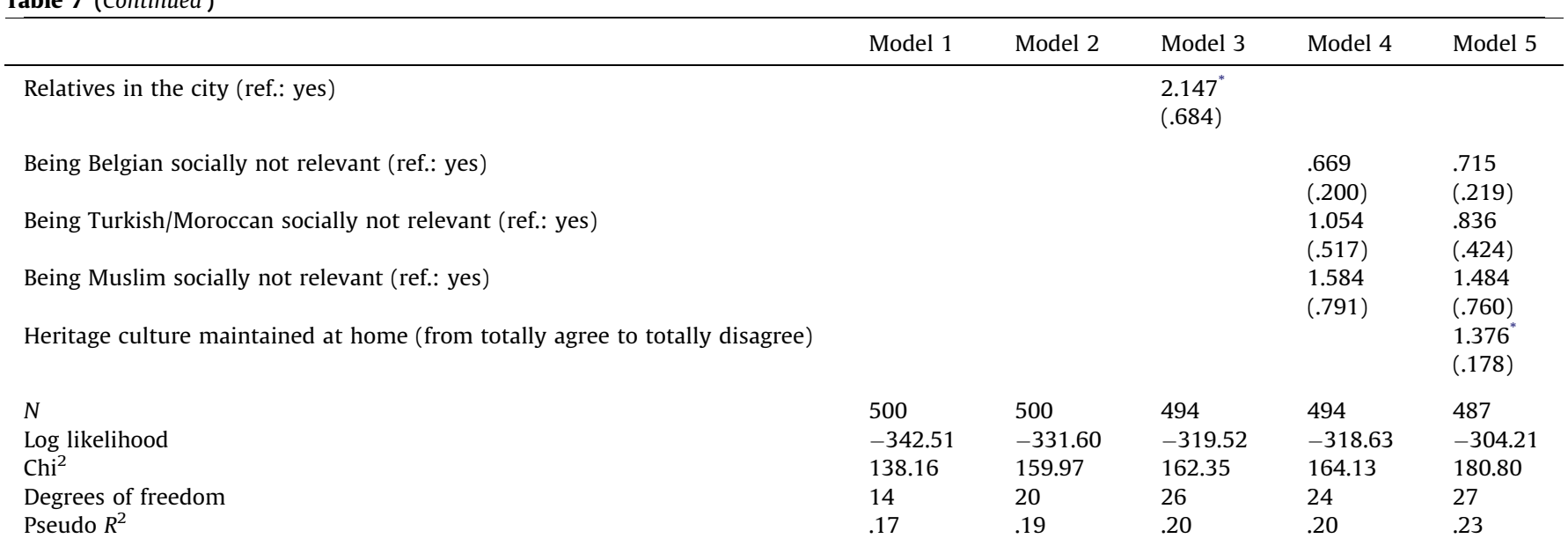

Source: TIES (Belgium), Turkish and Moroccan second generation with a partner only.

Notes: Reference category: first generation partner.

* $p<0.05$.

*** $p<0.01$.

$p<0.001$.

\subsection{Explanatory analysis}

Table 7 shows the final model of the multinomial logistic regressions estimated based on the sample of the descendents of migrants who do live with their partner. Compared to partnerships with a first generation partner, the determinants differ when looking at partnerships to native Belgians and to a second generation member.

One of the most important results in Table 7 is that Moroccans do not significantly differ from Turkish with regard to their marriage behaviour $(p>.05)$. Also, the interaction between sex and ethnic group was not found significant. Regarding geographic disparities, it is most likely in Antwerp to have a first generation immigrant as partner (odds ratio $>1$ ). It is more than twice as likely to choose for a second generation or native Belgian partner in Brussels. This confirms H5 that interethnic partnering is more probable in Antwerp. One explanation might indeed be the "ethnic conflict" argument raised earlier and that Brussels' population is by and large francophone, which could be a factor facilitating inter-ethnic partnerships (Lievens, 2000). It could also be that the contact hypothesis of Blau et al. (1982) and other authors holds true: the ethnic composition in Brussels is much more heterogeneous than in Antwerp, which could create more opportunities to meet inter-ethnic partners and limit the chances to meet someone from the same ethnic background.

The hypothesis that with increasing age it becomes more likely to live with a Belgian partner (H2) cannot be confirmed. The reason for this discrepancy with the pertinent literature might be that the age group is already limited but also that the data includes the second generation only. The assimilation effect that comes with age affecting intermarriage behaviour might hold true for first generation migrants but not for the second generation, who is born in Belgium. On the other hand, it becomes more likely with age to live with a first generation partner over a second generation partner.

The data seems to confirm the prediction that Belgian partners are more common in cohabitations rather than in marriages. In other words, non-married couples seem to be less homogamous (H8). (Note, however, that this vast effect is due to the small number of cohabiting couples in the reference outcome - due to unreliability in scarce cells, these odds must be interpreted with caution.)

Furthermore, the results suggest that women are twice as likely as men to choose first-generation partners over native Belgians and second generation partners. Other empirical studies on Belgium conclude that women and men have different motivations for marrying a first generation partner. For the Turkish minority, "marriage of a man to an import partner is motivated out of traditionalism, whereas women do so to accomplish their own agenda. [...] For women, the highest chance of being married to an import partner is found among those with the most modern characteristics, for men among those with the least modern characteristics." (Lievens, 1997: $18)^{5}$ Yet, in our study the interactions of gender with education and ethnicity were not found significant. ${ }^{6}$ As women are more educated this might offset the gender effect. The finding that women are less likely than men to have a Belgian native partner confirms $\mathrm{H} 7$ but raises the question if, as Corijn and Lodewijckx (2009) argue, this is indeed due to increased parental interference.

Many studies suggest that the context matters for partner choices. The social network (also referred to as third parties, see e.g. Kalmijn \& van Tubergen, 2007) impacts on the matching process of two persons through creating opportunities or mediation of family and friends. Yet, the models including variables on the parental position towards the union show that pressure to marry did not influence partner choice (output omitted). On the other hand, rejection of the partner by the parents has an

\footnotetext{
${ }^{5}$ The indicator of attitudes towards gender equality did not turn out as a relevant factor determining the partner choice.

${ }^{6}$ Since separate models for male and female subsamples were very similar (additional analyses available from the authors upon request), we present only cross-gender analyses and add significant interactions with gender.
} 
effect on the odds of living with a Belgian rather than a first generation partner (Models 3-5). Confirming H3, partnerships with Belgian natives go hand in hand with pressure to separate by the parents.

The odds of living with a second generation partner compared to living with a first generation partner are more than two times higher for medium and higher educated than for lower educated (Models 1-3). This multiplier effect is only significant for tertiary education when comparing first generation versus Belgian partners. The effect of tertiary education is on the other hand more pronounced (odds ratio $>4$ ). Briefly, H6 that education increases the odds of marrying/cohabitating a native Belgian holds true.

Human capital of the parents seems to partly impact on the partner choice. Although the father's educational background does not make a difference, tertiary education of the mother increases as expected the probability of having a native partner (Model 2). Yet, this effect disappears when controlling for parents' attitude towards the partner (Model 3, parental pressure to separate). Secondary education compared to lower educational attainments of the mother promotes having a second generation rather than a first generation partner (Models 2 and 3).

Surprisingly, also having native friends does not increase the odds of marrying a Belgian native rather than a first generation partner (Models 3-5). The composition of the social network, however, matters in the sense that the presence of relatives, which could have a similar influence on mating of the second generation as the parents, has a positive effect on finding a second generation partner. Yet, controlling for the effect of the social surrounding (friends, family and relatives) in Model 3, women do not become more likely to live with a Belgian native. Parental inference and other social capital characteristics do apparently not explain the gender gap regarding partner choices.

While this analysis gives some evidence on the importance of the parents in the mating process, the religious involvement of the parents is not relevant (output omitted). Yet, in line with $\mathrm{H} 4$, the importance of being a Muslim for the second generation respondent him/herself has a strong negative effect on having a Belgian native partner vis-a-vis having a first generation partner (Models 4 and 5). On the other hand, other ethnic boundaries (i.e. more precisely, being Belgian or Turkish/Moroccan is an important social category) do not have any impact on the partner choice. Similar findings were reported for the Netherlands by van Tubergen and Maas (2007). Briefly, religion is a relevant predictor but not if the person is raised religious but if $\mathrm{s} /$ he thinks it is an important social category. On the other hand, when the cultural heritage is maintained at home, the probability to have a Belgian native - but also a second generation - partner decreases.

\section{Discussion}

The analyses presented here have thrown additional light on the partnership patterns of the second generation in Belgium by including cohabitation and distinguishing three different types of partnerships. A first conclusion from the empirical analysis is that the inclusion of nonmarried but cohabiting unions is indispensible for obtaining an accurate and complete picture of partnership patterns. Family studies should thus broaden the scope beyond marriages, especially when looking at ethnic differences. The descents of Turkish and Moroccan immigrants in Belgium, the second generation, differ in their marital and cohabiting behaviour crucially from those of Belgian natives.

In line with assimilationist ideas, it is often assumed that successive immigrant generations assimilate and show higher rates of ethnic intermarriage than their parents and grandparents (e.g. Alba \& Nee, 2003; Qian \& Lichter, 2001). Language, culture and opportunity structures are held responsible. Previous research on intermarriage in Belgium suggests that the second generation women and men have lower chances to have a first generation partner than the first and 1.5 generation (Lievens, 1997). Our study contributes to this literature by raising the question how to conceptualise inter-ethnic unions. We have showed that most of the relations to Belgians are in fact unions with partners of the second generation from the same ethnic background and conclude that estimations of inter-ethnic partnerships based on relations to first generation immigrants seriously underestimate the extent of intra-ethnic partnerships. Although it was not possible to perform an inter-generational comparison here, the high share of intra-ethnic cohabiting unions points towards the conclusions of other authors, namely that the assimilation thesis (understanding assimilation roughly as decreasing disparities or increasing similarities between life chances and life styles between 'immigrant origin' groups and a relevant 'non-immigrant origin' reference group) does not necessarily hold in the Belgian context (Callaerts, 1997; Lievens, 1996, 1997; Reniers \& Lievens, 1997; Reniers, 1998; see also Milewski \& Hamel, 2010).

Regarding the determinants of the partner choice, our findings, which are based on data from the Belgian TIES project, are to a large extent consistent with other studies on inter-ethnic partnerships. This study confirmed the positive effect of higher education and the mother's education as well as regional and gendered differences of earlier studies on intermarriage. Results that could not be confirmed relate to age and gendered effects of ethnicity and education. Also language skills were not found relevant. Reasons for these discrepancies could be the homogeneity of the sample, which comprises only the second generation born in Belgium.

The analysis tested not only individual characteristics but also accounted for the nature of the respondent's social environment. The number of inter-ethnic contacts in one's personal network did not have the expected positive effect on the chances to have an inter-ethnic partner. Parents but also the wider family, however, played an important role for the partner choice. Precisely, living with a Belgian is associated with an increased likelihood of parental reservations towards the partner. Yet, this association may bear an endogeneity effect. In case of problems in the relation, parents could increasingly push their children to separate from their partner. In this case, the variable is 
rather an indicator of the quality (conflict level/instability) of the relationship than the parents' preferences towards their children's partner.

In addition to previous research, we were able to incorporate attitudinal determinants of partner choice, which allows us to challenge and refine previous findings. In line with other studies (van Tubergen \& Maas, 2007), not religion but its subjective importance as a social category decreased the odds of an interethnic-partnership. Yet, this did not hold true for other ethnic boundaries (Belgium versus country of origin). Finally, if the maintenance of cultural heritage at home was attached much importance, it became less likely to choose a Belgian native over a firstgeneration partner. This, together with the finding of the importance of religion, poses questions about the interdependence and reciprocity of ethnic identity and interethnic partnerships, which should be addressed by future research. However, limited by data restrictions, the rather crude operationalisation of the theoretical concepts "parental involvement", "religiosity" and "cultural maintenance at home" only represents a first step towards answering such questions but needs to be refined in future studies.

\section{References}

Alba, R., \& Nee, V. (2003). Remaking the American Mainstream. Cambridge: Cambridge University Press.

Backhaus, K., Erichson, B., Plinke, W., \& Weiber, R. (2006). Multivariate Analysemethoden. Berlin: Springer.

Barth, F. (1969). Ethnic groups and boundaries: The social organization of cultural difference. Boston: Little, Brown.

Blackwell, D. L., \& Lichter, D. T. (2000). Mate selection among married and cohabiting couples. Journal of Family Issues, 21, 275-302.

Blau, P. M., Blum, T. C., \& Schwartz, J. E. (1982). Heterogeneity and intermarriage. American Sociological Review, 47(1), 45-62.

Callaerts, T. (1997). 'Import' huwelijken bij Jonge Turkse Migranten in Vlaanderen en Brussel: een Kwalitatieve Benadering. Vrije Universiteit Brussel, Working Papers Etnische Minderheden in Belgie (1997-2).

Corijn, M. (2010). Het profiel van de niet-gehuwd samenwonenden in het Vlaams Gewest. SVR-Webartikel (2010/18).

Corijn, M., \& Klijzing, E. (Eds.). (2001). Transitions to adulthood in Europe. London: Kluwer Academic Publishers.

Corijn, M., \& Lodewijckx, E. (2009). De start van de gezinsvorming bij de Turkse en Marokkaanse tweede generatie in het Vlaamse Gewest. SVR Rapport. S. v. d. V. Regering. Brussel: Vlaamse Overheid.

Esveldt, I., Kulu-Glasgow, I., Schoorl, J. J., \& van Solinge, H. (1995). Migratiemotieven, Migratienetwerken en Partnerkeuze van Turken en Markkanen in Nederland. Den Haag: NIDI.

Gordon, M. M. (1964). Assimilation in American life: The role of race, religion, and national origins. New York: Oxford University Press.

Huschek, D., Liefbroer, A. C., \& de Valk, H. A. G. (2010). Timing of first union among second-generation Turks in Europe: The role of parents, peers and institutional context. Demographic Research, 22(16), 473-504.
Kalmijn, M. (1991). Status homogamy in the United States. The American Journal of Sociology, 97(2), 496-523.

Kalmijn, M. (1994). Assortative mating by cultural and economic occupational status. The American Journal of Sociology, 100(2), 422-452.

Kalmijn, M. (1998). Intermarriage and homogamy: Causes, patterns, trends. Annual Review of Sociology, 24, 395-421.

Kalmijn, M., \& van Tubergen, F. (2007). Ethnic intermarriage in the Netherlands: Confirmations and refutations of accepted insights. European Journal of Population, 22, 371-397.

Lesthaeghe, R. (2000). Transnational Islamic communities in a multilingual secular society. In R. Lesthaeghe (Ed.), Communities and generations. Turkish and Moroccan populations in Belgium. Brussels: VUB Press.

Lievens, J. (1996). Krachtlijnen van gezinsvormende migratie. Working Papers "Etnische Minderheden in Belgie" (1996-3).

Lievens, J. (1997). The Third Wave of Immigration from Turkey and Morocco: Determinants and Characteristics. Universiteit Gent, Interuniversity papers in demography (IPD) (1997-2).

Lievens, J. (1998). Interethnic marriage: Bringing in the context through multilevel modelling. European Journal of Population, 14, 117-155.

Lievens, J. (2000). The third wave of immigration from Turkey and Morocco. In R. Lesthaeghe (Ed.), Communities and generations. Turkish and Moroccan populations in Belgium. Brussels: VUB Press.

Lodewijckx, E. (2010). Gezinsvorming bij de tweede generatie Turken en Marokkanen. Een verschillende start al naargelang ze huwen met een huwelijksmigrant of met iemand van de tweede generatie? SVR-Webartikel (2010/22).

Lucassen, L., \& Laarman, C. (2009). Immigration, intermarriage and the changing face of Europe in the post war period. History of the family, $14,52-68$.

Milewski, N., \& Hamel, C. (2010). Union formation and partner choice in a transnational context: The case of descendants of Turkish immigrants in France. International Migration Review, 44(3), 615-658.

Qian, Z., \& Lichter, D. T. (2001). Measuring marital assimilation: Intermarriage among natives and immigrants. Social Science Research, 30, 289-312.

Reniers, G. (1998). Post-migration survival of traditional marriage patterns: Consanguineous marriage among Turkish and Moroccan immigrants in Belgium. Universiteit Gent, Interuniversity papers in demography (IPD) (1998-1).

Reniers, G., \& Lievens, J. (1997). Stereotypen in perspectief. De evolutie van enkele aspecten van het huwelijk bij de Turkse en Marokkaanse minderheden in Belgie. Working Papers "Etnische Minderheden in Belgie" (Universiteit Gent, Vakgroep Bevolkingswetenschappen) (1996-3).

Schoenmaeckers, R. C., Lodewijckx, E., \& Gadeyne, S. (1999). Marriages and fertility among Turkish and Moroccan Women in Belgium: Results from census data. International Migration Review, 33(4), 901-928.

Sherkat, D. E. (2004). Religious intermarriage in the United States: Trends, patterns, and predictors. Social Science Research, 33, 606-625.

Song, M. (2009). Is intermarriage a good indicator of integration? Journal of Ethnic and Migration Studies, 35(2), 331-348.

Swyngedouw, M., Phalet, K., Baysu, G., Vandezande, V., \& Fleischmann, F. (2008). Technical Report. TIES 2007-2008 Belgium-Extended Trajectories and Experiences of Turkish, Moroccan and Native Belgians in Antwerp and Brussels. Leuven: Center for Sociological (CeSo), University of Leuven and Center for Social and Cultural Psychology (CSCP).

van Tubergen, F., \& Maas, I. (2007). Ethnic intermarriage among immigrants in the Netherlands: An analysis of population data. Social Science Research, 36, 1065-1086.

Vandezande, V., Phalet, K., \& Swyngedouw, M. (2011). Do feelings of discrimination explain the riots in Brussels? A comparison of Moroccan and Turkish groups in Brussels and Antwerp. Brussels Studies 47.

Van der Hoek, J., \& Kret, M. (1992). Marokkaanse tienermeisjes: gezinsvloeden op keuzen en kansen. Utrecht: Van Arkel. 